\title{
Impact of dengue-preventive behaviors on Aedes immature production in Bang Kachao, Samut Prakan Province, Thailand: a cross-sectional study
}

\author{
Pathavee Waewwab ${ }^{1}$, Sungsit Sungvornyothin ${ }^{1 *}$, Rutcharin Potiwat ${ }^{1}$ and Kamolnetr Okanurak ${ }^{2^{*}}$ (D)
}

\begin{abstract}
Background: Controlling sites where mosquitos breed is a key strategy in breaking the cycle of infectious transmission of the dengue virus. Preventive behaviors, such as covering water containers with lids and adding temephos (commercially named Abate sand) in water containers are needed to reduce and control mosquito breeding sites. This study aimed to investigate the impact of dengue-preventive behaviors on Aedes immature production.

Methods: This cross-sectional study used in-person interviews to record occurrence of dengue-preventive behaviors in Bang Kachao, Samut Prakan Province, Thailand. Larval mosquitos in and around houses were observed and recorded, and covered 208 households.

Results: It was found that $50 \%$ of these households had containers for drinking water and $94 \%$ used water containers. Covering water containers with effective lids showed the best success among dengue-preventive behaviors for reducing Aedes immature production. Adding temephos in water containers also was effective.
\end{abstract}

Conclusions: Such behaviors substantively affected development of Aedes immatures in and around households.

Keywords: Dengue prevention, Behavior, Aedes immature production, Vector control

\section{Background}

The World Health Organization (WHO) regards dengue as an emerging and re-emerging mosquito-borne viral disease. Over the last 50 years, dengue has dramatically spread and increased in various locations. Southeast Asia and the Western Pacific in particular have been seriously affected [1]. In Thailand, the first dengue cases were reported in Bangkok in 1949. The first dengue outbreak was in 1958, with 2158 documented cases and 300 deaths [2], The two largest dengue outbreaks in Thailand were in 1997 and 1998,

\footnotetext{
*Correspondence: s.sungsit@gmail.com; kamolnetr.oka@mahidol.ac.th 'Department of Medical Entomology, Faculty of Tropical Medicine, Mahidol University, Bangkok 10400, Thailand

${ }^{2}$ Department of Social and Environmental Medicine, Faculty of Tropical Medicine, Mahidol University, Bangkok 10400, Thailand
}

with 101,689 and 126,348 cases, respectively [3, 4]. Dengue is now gradually spreading to rural areas in several parts of Thailand [5].

Dengue is transmitted by Aedes spp. mosquitoes, namely Aedes aegypti and Aedes albopictus, throughout tropical and sub-tropical areas [6]. Female Aedes mosquitoes have adapted to improve their chance of life [7], particularly in finding breeding sites for laying eggs in water-holding containers, such as earthen jars used for domestic water storage, flower pots, tires, flower vases, pet water bowls, and disposed of items that fill with rainwater. They can also breed in natural containers, such as tree holes, leaf axils, and coconut shells [8]. The main breeding sites in Thailand were found in earthen jars and in large, rectangular cement containers used to store water for

(c) The Author(s). 2020 Open Access This article is licensed under a Creative Commons Attribution 4.0 International License, which permits use, sharing, adaptation, distribution and reproduction in any medium or format, as long as you give appropriate credit to the original author(s) and the source, provide a link to the Creative Commons licence, and indicate if changes were made. The images or other third party material in this article are included in the article's Creative Commons licence, unless indicated otherwise in a credit line to the material. If material is not included in the article's Creative Commons licence and your intended use is not permitted by statutory regulation or exceeds the permitted use, you will need to obtain permission directly from the copyright holder. To view a copy of this licence, visit http://creativecommons.org/licenses/by/4.0/. The Creative Commons Public Domain Dedication waiver (http://creativecommons.org/publicdomain/zero/1.0/) applies to the data made available in this article, unless otherwise stated in a credit line to the data. 
bathing and for flushing toilets [9]. Because of the close relationship between Aedes spp. mosquitoes and waterholding containers in/around human houses, vectorcontrol strategies focus on reducing sources of Aedes immature (larva and pupa) habitats [10].

As dengue vaccination has limited use, mosquito control remains a vital strategy for preventing and controlling dengue transmission [11]. The WHO noted that water containers without secure lids or tightly fitted mesh screens are potentially the best breeding sites for Aedes mosquitoes [12]. Another dengue vector control measure is use of temephos (commercially named Abate sand) as a larvicide. Temephos can be used safely in potable and daily-use water, is recommended by the WHO [13], and is highly effective against Aedes larvae [14, 15]. However, its efficacy can be degraded by temperature, organic debris, exposure to sunlight, water use patterns, maintenance of water containers, and refusal to use it in households because of its unpleasant odor [16, 17]. Frequent changing and cleaning of water containers is also effective for considerably reducing Aedes larval abundance in households [9, 18]. Additionally, overturning water containers after use, and removing disposed items around the household can help reduce potentially active breeding areas of mosquitoes, thereby reducing Aedes immature abundance [19]. Previous studies have revealed many denguepreventive behaviors that can impact Aedes immature production [9, 12, 14, 15, 18-20].

The Ministry of Public Health of Thailand has implemented dengue prevention and control measures called the "3 Do's": 1) routinely empty or cover water-storage containers, 2) properly dispose of garbage, and 3) keep houses neat and orderly (Department of Disease Control, Ministry of Public Health of Thailand, 2016).

The present study aimed to investigate the impact of dengue-preventive behaviors on Aedes immature production.

\section{Methods}

\section{Study design and study area}

A cross-sectional study was conducted in Bang Kachao, Samut Prakan Province, Thailand $\left(13^{\circ} 14^{\prime} \mathrm{N}\right.$ latitude, $100^{\circ} 33^{\prime} \mathrm{E}$ longitude) during its rainy season (July-September) in 2017. The study areas covered the five villages with the highest dengue incidence rates in Bang Kachao: Ban Hua Ro, Ban Nam Chon, Ban Bang Nam Phueng, Ban Khlong Mon, and Ban Khlong Pae.

\section{Sample size estimation}

The sample size was calculated based on the following formula [21]:

$$
n=\frac{N p(1-p) Z^{2}}{d^{2}(N-1)+p(1-p) Z^{2}}
$$

where $\mathrm{n}$ was the sample size, $\mathrm{N}$ was 448 households from the five villages, $\mathrm{Z}^{2}$ was the standard $95 \%$ confidence interval for a two-sided test (1.96), $\mathrm{p}$ was the percentage of households using dengue vector control measures [22], and $\mathrm{d}^{2}$ was acceptable completed error (0.05). From the calculation, the study covered 204 households.

\section{Data collection and data analysis}

Field surveys were conducted by three teams, each consisting of two entomologists, a research assistant, and a village heath volunteer. For each interview, the health volunteer first requested permission, then the research assistant interviewed the head of the household, or a representative, by using a structured questionnaire regarding dengue-preventive behaviors. The research objectives and process were explained, and signed, written informed consent to take part in the study was received from each participant. Two entomologists looked for indoor and outdoor water-holding containers and for

Table 1 Proportion of container with Aedes immature mosquito per wet container and per household

\begin{tabular}{|c|c|c|c|c|c|}
\hline Type of container & $\begin{array}{l}\text { No. of households } \\
\text { had containers }\end{array}$ & $\begin{array}{l}\text { No. of wet } \\
\text { containers }\end{array}$ & $\begin{array}{l}\text { No. containers } \\
\text { with immature } \\
\text { mosquito }\end{array}$ & $\begin{array}{l}\text { Proportion of container } \\
\text { with immature mosquito } \\
\text { per wet container }\end{array}$ & $\begin{array}{l}\text { Proportion of container } \\
\text { with immature mosquito } \\
\text { per household }\end{array}$ \\
\hline Drinking water & 105 & 115 & 2 & 0.02 & 0.02 \\
\hline Used water & 208 & 250 & 115 & 0.46 & 0.55 \\
\hline Flower vase & 116 & 137 & 5 & 0.04 & 0.04 \\
\hline Pet water bowl & 103 & 108 & 7 & 0.06 & 0.07 \\
\hline Flower pot & 31 & 63 & 19 & 0.30 & 0.61 \\
\hline Unused outdoor & 208 & 375 & 16 & 0.04 & 0.08 \\
\hline Water bucket or can & 117 & 132 & 7 & 0.05 & 0.06 \\
\hline $\begin{array}{l}\text { Water bowl or glass at cemetery and/or spirit } \\
\text { house }\end{array}$ & 111 & 267 & 7 & 0.03 & 0.06 \\
\hline Tire & 21 & 157 & 7 & 0.04 & 0.33 \\
\hline
\end{tabular}


Aedes immatures (larvae and pupae) in such containers. A household found Aedes immature production was recorded as "the presence of Aedes immature production, and a household with free of Aedes immature production was recorded as "the absence of Aedes immature production. All Aedes immatures were collected in labeled plastic bottles, recorded and transported to the laboratory at the Medical Entomology Insectarium, Faculty of Tropical Medicine, Mahidol University. All Aedes immatures were counted. All larvae were identified by species while all pupae were reared to their adult stage before species identification.

Statistical analyses were performed using a statistical program, namely STATA version 14.0 licensed to Mahidol University (Serial number: 401406001858). Descriptive analysis was performed for Aedes immatures observed in positive containers and for denguepreventive behavior in households. The impact of dengue-preventive behaviors on the presence of Aedes immature production was analyzed using binary logistic regression, reporting odds ratios. Dengue-preventive behaviors were included as predictors and the presence of Aedes immature production as response variables.

\section{Results}

As mentioned, the study covered 208 households in five villages in Bang Kachao. Of these, 105 had drinking water containers (50.48\%), and 196 used some form of water container (94.23\%). A total of 116 had water vases (55.77\%), $103 \mathrm{had}$ pet water bowls (49.51\%), and 31 had flower pots (14.90\%). There were 145 that washed water containers with a brush or sponge (69.71\%), 42 threw away any unused outdoor containers (20.19\%), and 71 overturned other containers, such as water buckets or cans, after use (34.13\%).

\section{Aedes immature abundance}

A total of 3802 Aedes immatures were collected, of which 3725 (97.97\%) were Aedes aegypti and 77 (2.03\%) were Aedes albopictus. When observing the proportion of immature mosquito positive container per household, it was found that household with flower pot to be highly infested with Aedes immatures (61\%). Households storing used water $(15.38 \%)$ in bathroom and/or toilet containers, small jars, and large jars were found to be more highly infested with Aedes immatures (55\%) than were households storing drinking water (2\%) (Table 1).

\section{Dengue-preventive behaviors}

More than $98 \%$ of the surveyed households covered their drinking water containers with lids. More than half used water containers with lids and added temephos. About $12 \%$ used neither of those methods. Additionally, more than $86 \%$ changed water or added temephos in water vases, and $85.43 \%$ changed water in pet water bowls. Approximately $74 \%$ did not empty water from flower saucers and about $80 \%$ did not throw out unused outdoor containers. Of the surveyed households, almost $70 \%$ washed their water containers with a brush or sponge. About $54 \%$ overturned other containers, such as water buckets or cans, after use (Table 2).

The households that covered drinking water containers with effective lids showed the best denguepreventive behavior. Households not covering lids on drinking water were 4 times more likely to have $A e$ des immature stages than those using effective lids $(\mathrm{OR}=4.0, p$ value $<0.001)$. Those not covering lids on used water containers were 3.4 times more likely to have Aedes immature stages compared to those using effective lids $(\mathrm{OR}=3.4, p$ value $<0.001)$. While those adding temephos in used water containers were 1.5 times more likely to have Aedes immature stages compared to those using effective lids $(\mathrm{OR}=1.48, p$ value $<0.001)$. Households that both covered used water containers with

Table 2 Dengue preventive behaviors surveyed in households

\begin{tabular}{|c|c|c|}
\hline Variables & $\begin{array}{l}\text { No. of inspected } \\
\text { households }\end{array}$ & $\%$ \\
\hline \multicolumn{3}{|l|}{ Container for drinking water } \\
\hline - No lid & 2 & 1.91 \\
\hline - Covered with effective lid & 103 & 98.09 \\
\hline \multicolumn{3}{|l|}{ Container for used water } \\
\hline - No lid or temephos & 24 & 11.54 \\
\hline - Added temephos & 37 & 17.79 \\
\hline - Had effective lid & 47 & 22.59 \\
\hline $\begin{array}{l}\text { - Had effective lid and added } \\
\text { temephos }\end{array}$ & 100 & 48.08 \\
\hline \multicolumn{3}{|c|}{ Changed water or added temephos in vase } \\
\hline$-\mathrm{No}$ & 16 & 13.79 \\
\hline - Yes & 100 & 86.21 \\
\hline \multicolumn{3}{|l|}{ Changed water in pet water bowl } \\
\hline- No & 15 & 14.56 \\
\hline - Yes & 88 & 85.44 \\
\hline \multicolumn{3}{|l|}{ Emptied water from flower pot } \\
\hline- No & 23 & 74.19 \\
\hline - Yes & 8 & 25.81 \\
\hline \multicolumn{3}{|c|}{ Washed water container with brush or sponge } \\
\hline$-\mathrm{No}$ & 63 & 30.29 \\
\hline - Yes & 145 & 69.71 \\
\hline \multicolumn{3}{|c|}{ Thrown away unused outdoor containers } \\
\hline$-\mathrm{No}$ & 166 & 79.81 \\
\hline - Yes & 42 & 20.19 \\
\hline \multicolumn{3}{|l|}{ Overturned other containers after use } \\
\hline- No & 46 & 39.32 \\
\hline - Yes & 8 & 6.83 \\
\hline - Yes, and kept away from rain & 63 & 53.85 \\
\hline
\end{tabular}


lids and added temephos were 1.7 times more likely to have Aedes immature stages compared to those using effective lids $(\mathrm{OR}=1.69, p$ value $<0.001)$. It was also found that the households did not empty water from flower pots were 2.4 times more likely to have Aedes immature stages compared to those emptied water $(\mathrm{OR}=2.43, p$ value $<0.001)$. House that did not change water or added temephos in water vases were 1.9 times more likely to have Aedes immature stages compared to those that $\operatorname{did}(\mathrm{OR}=1.85, p$ value $<0.001)$. It was also found households that did not overturned other container after use or kept away from rain were 1.3 times more likely to have Aedes immature compared with those that did $(\mathrm{OR}=1.29$, $\mathrm{p}$ value $=0.001)($ Table 3$)$.

\section{Discussion}

This study showed that covering drinking and used water storage containers with effective lids had a substantial positive impact toward dengue prevention. A previous study had similar findings for household water containers [9]. Adding temephos in used water containers was also found to be an effective denguepreventive behavior. Previous studies found temephos was effective against Aedes mosquito larvae [14, 15]. Additionally, the present study found that both covering lids and adding temephos had a substantial impact on reducing Aedes immatures. In line with this, a previous study also found greater efficacy in using a combination of dengue control methods [9].

The present study found that covering water containers with lids was more effective than adding temephos for preventing Aedes immature production. The WHO also reported that use of effective lids is a lowercost vector control than using insecticide [12]. On the other hand, the effectiveness of abate sand may decrease from sunlight that possibly degraded the active compound of temephos [16]. Moreover, households may frequently drain and refill water containers, which could

Table 3 Binary logistic regression analysis of dengue-preventive behaviors affecting the presence of Aedes immature production

\begin{tabular}{|c|c|c|c|}
\hline Variables & Odds Ratios & 95\% Confidence Interval & $P$ value \\
\hline \multicolumn{4}{|l|}{ Container for drinking water $(n=105)$} \\
\hline - No lid & 4.00 & $2.94-5.26$ & $<0.001^{*}$ \\
\hline - Covered with effective lid (reference) & 1.00 & & \\
\hline \multicolumn{4}{|l|}{ Container for used water covered by lid $(n=208)$} \\
\hline - No lid or temephos & 3.45 & $2.63-4.35$ & $<0.001^{*}$ \\
\hline - Added temephos & 1.48 & $1.28-1.59$ & $<0.001^{*}$ \\
\hline - Had effective lid (Reference) & 1.00 & & \\
\hline - Had effective lid and added temephos & 1.69 & $1.61-1.75$ & $<0.001^{*}$ \\
\hline \multicolumn{4}{|c|}{ Changed water or added temephos in vase $(n=116)$} \\
\hline$-\mathrm{No}$ & 1.85 & $1.69-2.00$ & $<0.001^{*}$ \\
\hline - Yes (reference) & 1.00 & & \\
\hline \multicolumn{4}{|l|}{ Changed water in pet water bowl $(n=103)$} \\
\hline- No & 1.09 & $1.02-1.17$ & $0.015^{*}$ \\
\hline - Yes (reference) & 1.00 & & \\
\hline \multicolumn{4}{|l|}{ Emptied water from flower pot $(n=31)$} \\
\hline- No & 2.43 & $2.08-2.77$ & $<0.001^{*}$ \\
\hline - Yes (reference) & 1.00 & & \\
\hline \multicolumn{4}{|c|}{ Washed water container with brush or sponge $(n=208)$} \\
\hline- No & 1.01 & $0.92-1.11$ & 0.839 \\
\hline - Yes (reference) & 1.00 & & \\
\hline \multicolumn{4}{|l|}{ Throw away unused outdoor containers $(n=208)$} \\
\hline- No & 1.12 & $1.04-1.23$ & $0.005^{*}$ \\
\hline - Yes (reference) & 1.00 & & \\
\hline \multicolumn{4}{|l|}{ Overturned other containers after use $(n=117)$} \\
\hline - No & 1.29 & $1.12-1.51$ & $0.001^{*}$ \\
\hline - Yes & 1.03 & $0.94-1.18$ & 0.690 \\
\hline - Yes, and kept away from rain (reference) & 1.00 & & \\
\hline
\end{tabular}


shorten temephos' residual effectiveness [16]. Additionally, another study found temephos to provide effective control for 2.5-5 (mean, 3) months [23]. The present study also found that cover water containers with lids was superior to both using a lid and adding temephos. This may be because those who took both measures did not perform them both regularly. Distributing free temephos may therefore not justify the necessary time and effort. Based on this, the Ministry of Public Health should change its health prevention strategy from distributing free temephos to subsidizing lids.

Other water containers identified as Aedes mosquito breeding sites were flower pots (and their saucers), pet water bowls, water vases, and unused outdoor containers. Emptying water from flower pots was found effective at dengue control. Changing water or adding temephos in water vases and pet water bowls were also effective preventive behaviors. Previous studies reported that avoiding retaining water in such containers was potentially effective at larval control $[9,21]$. Another study reported that removal of unused outdoor containers around houses was effective for reducing sources of mosquito breeding sites [18].

Water buckets and cans were other Aedes mosquito breeding sites. The present study found it effective to overturn these containers or keep them away from rain. Overturning them decreased how much rainwater they held.

Previous studies reported that washing containers with a brush or sponge to remove mosquito eggs was effective for dengue control [9, 17, 22, 24-26]; however, this study did not find that relationship. This might be because some water containers were large and therefore difficult to wash, especially those that were rectangular, cement, and built in the bathroom corner. Thus, the container's size may affect the frequency of washing.

This study was limited by collecting data only once, hence the presence of Aedes immature production and dengue-preventive behaviors observed in a household cannot represent all seasons. The data collection covered only 208 households, so it might not be sufficient to represent Thailand.

\section{Conclusions}

This study found that covering water containers with effective lids was the most effective method for controlling Aedes immature production. Adding temephos to water is also potentially effective. Public health messages should therefore focus on the use of lids, as this appears most successful and costs less than temephos.

Abbreviation

WHO: World Health Organization

\section{Acknowledgments}

We would like to thank all participants who gave the valuable information in this study. We also thank Adam Goulston, MS, ELS, from Edanz Group (www.edanzediting.com/ac) for editing a draft of this manuscript.

\section{Authors' contributions}

Data acquisition and drafting the work were performed by PW. KO designed methodology. $\mathrm{KO}$ and SS revised the manuscript. KO, SS, PW and RP analyzed and interpreted the data. All authors read and approved the final manuscript.

\section{Funding}

This work was supported by National Research Council of Thailand (FY2017 thesis grant for doctoral degree student). The funding body has no role in the design of the study and collection, analysis, and interpretation of data and in writing the manuscript.

\section{Availability of data and materials \\ Not applicable.}

\section{Ethics approval and consent to participate}

The study was approved by the Ethics Committee of the Faculty of Tropical Medicine, Mahidol University (MUTM 2016-068-01) and the Mahidol University-Institute Animal Care and Use Committee, Mahidol University (MUIACUC 2016/023). Participants were enrolled in the study after giving written informed consent.

\section{Consent for publication}

Not applicable.

\section{Competing interests}

The authors declare that they have no competing interests.

Received: 30 October 2018 Accepted: 24 February 2020

Published online: 11 June 2020

\section{References}

1. Murray NEA, Quam MB, Wilder-Smith A. Epidemiology of dengue: past, present and future prospects. Clin Epidemiol. 2013;5:299-309.

2. Gubler DJ. Dengue and dengue hemorrhagic fever. Clin Microbiol Rev. 1998;11(3):480-96.

3. Rojanapithayakorn W: Dengue haemorrhagic fever in Thailand. In.: Dengue Bull 22; 1998.

4. WHO Regional Office for Southeast Asia: Reported cases of DF/DHF in selected countries in SEA region (1985-2005). In.; 2007.

5. World Health Organization Regional Office for South-East Asia: Neglected tropical diseases In.; 2017.

6. Mike Service: Medical entomology for students, 4th edn. Cambridge, United Kingdom: Cambridge university press; 2008.

7. Clements AN. The biology of mosquitoes volume 1:development, nutrition and reproduction, vol. 1. London: Chapman \& Hall; 1992.

8. Dengue and the Aedes aegypti mosquito [http://www.cdc.gov/dengue/ resources/30Jan2012/aegyptifactsheet.pdf].

9. Phuanukoonnon S, Mueller I, Bryan JH. Effectiveness of dengue control practices in household water containers in Northeast Thailand. Tropical Med Int Health. 2005;10(8):755-63.

10. Hiscox A, Kaye A, Vongphayloth K, Banks I, Piffer M, Khammanithong P, Sananikhom P, Kaul S, Hill N, Lindsay SW, et al. Risk factors for the presence of Aedes aegypti and Aedes albopictus in domestic water-holding Containers in Areas Impacted by the Nam Theun 2 hydroelectric project, Laos. The American journal of tropical medicine and hygiene. 2013;88(6):1070-8.

11. Guzman MG, Mune M, Kouri G. Dengue vaccine: priorities and progress. Expert Rev Anti-Infect Ther. 2004;2(6):895-911.

12. World Health Organization: Dengue: guidelines for diagnosis, treatment, prevention and control. In. Geneva; 2009.

13. World Health Organization: WHO Specifications and evaluations for public health pesticides: Temephos. In. Geneva; 2008.

14. Garza-Robledo AA, Martinez-Perales JF, Rodriguez-Castro VA, QuirozMartinez $\mathrm{H}$. Effectiveness of spinosad and temephos for the control of 
mosquito larvae at a tire dump in Allende, Nuevo Leon, Mexico. J Am Mosq Control Assoc. 2011;27(4):404-7.

15. Marina CF, Bond JG, Casas M, Munoz J, Orozco A, Valle J, Williams T. Spinosad as an effective lanvicide for control of Aedes albopictus and Aedes aegypti, vectors of dengue in southern Mexico. Pest Manag Sci. 2011;67(1):114-21.

16. Thavara U, Tawatsin A, Kong-Ngamsuk W, Mulla MS. Efficacy and longevity of a new formulation of temephos larvicide tested in village-scale trials against larval Aedes aegypti in water-storage containers. J Am Mosq Control Assoc. 2004;20(2):176-82.

17. George L, Lenhart A, Toledo J, Lazaro A, Han WW, Velayudhan R, Runge Ranzinger S, Horstick O. Community-effectiveness of Temephos for dengue vector control: a systematic literature review. PLoS Negl Trop Dis. 2015;9(9): e0004006.

18. Ferdousi F, Yoshimatsu S, Ma E, Sohel N, Wagatsuma Y. Identification of essential Containers for Aedes Larval Breeding to control denque in Dhaka, Bangladesh. Trop Med Health. 2015;43(4):253-64.

19. Nazri CD, Hashim A, Rodziah AH, Abu Yazid A. Utilization of geoinformation tools for dengue control management strategy: a case study in Seberang Prai, Penang Malaysia. International Journal of Remote Sensing Application. 2013;3:11-7.

20. Foo LC, Lim TW, Lee HL, Fang R. Rainfall, abundance of Aedes aegypti and dengue infection in Selangor, Malaysia. Southeast Asian J Trop Med Public Health. 1986;16:560-8.

21. Arunachalam N, Tana S, Espino F, Kittayapong P, Abeyewickreme W, Wai KT, Tyagi BK, Kroeger A, Sommerfeld J, Petzold M. Eco-bio-social determinants of dengue vector breeding: a multicountry study in urban and periurban Asia. Bull World Health Organ. 2010;88(3):173-84.

22. Kittayapong $\mathrm{P}$, Thongyuan S, Olanratmanee $\mathrm{P}$, Aumchareoun W, Koyadun S, Kittayapong R, Butraporn P. Application of eco-friendly tools and eco-biosocial strategies to control dengue vectors in urban and peri-urban settings in Thailand. Pathogens and Global Health. 2012;106(8):446-54.

23. Bang YH, Tonn RJ, Jatanasen S. Pilot studies of abate as a larvicide for control of Aedes aegypti in Bangkok, Thailand. Southeast Asian J Trop Med Public Health. 1972;3(1):106-15

24. Dengue control: Environmental management [http://www.who.int/ denguecontrol/control_strategies/environmental_management/en/].

25. Vannavong N, Seidu R, Stenström T-A, Dada N, Overgaard HJ. Effects of socio-demographic characteristics and household water management on Aedes aegypti production in suburban and rural villages in Laos and Thailand. Parasit Vectors. 2017;10(1):170

26. Walker KR, Williamson D, Carrière Y, Reyes-Castro PA, Haenchen S, Hayden MH, Jeffrey Gutierrez E, Ernst KC: Socioeconomic and Human Behavioral Factors Associated With Aedes aegypti (Diptera: Culicidae) Immature Habitat in Tucson, AZ. Journal of Medical Entomology 2018:tjy011-tjy011.

\section{Publisher's Note}

Springer Nature remains neutral with regard to jurisdictional claims in published maps and institutional affiliations.

Ready to submit your research? Choose BMC and benefit from:

- fast, convenient online submission

- thorough peer review by experienced researchers in your field

- rapid publication on acceptance

- support for research data, including large and complex data types

- gold Open Access which fosters wider collaboration and increased citations

- maximum visibility for your research: over $100 \mathrm{M}$ website views per year

At $\mathrm{BMC}$, research is always in progress.

Learn more biomedcentral.com/submissions 